\title{
住宅市場圈構成から見た平成市町村大合併の検討 MUNICIPAL MERGER STUDIED FROM A VIEWPOINT OF THE STRUCTURE IN DAILY LIFE BASED HOUSING MARKET AREA
}

\author{
眞嶋二 郎* \\ Jiroh MAJIMA
}

\begin{abstract}
This study analyses structural problems of the newly created administrative districts due to the recent municipal merger, through the structure of housing market areas as daily life areas.

The following results were found: 1) The number of municipalities reduced in half due to the merger between 2000 and 2010 .

2) The population in each city has increased because of the merger of small municipalities into bigger existing or newly created cities. 3) $30 \%$ of merged municipalities contain fractions of more than one housing market areas, and the half of the daily life areas had significant influence by the merger. 4) South western parts of Japan have more merged municipalities than big cities and some parts of eastern Japan.
\end{abstract}

Keywords: Housing Market Area, Municipal Merger, Daily Life Area 市町村合併、住宅市場圈、日常生活圈

\section{1. 研究の目的と方法}

1953〜1961 年の昭和の大合併では、主としてコミュニティ形成に 関わる新制中学の効率的設置のために町村の標準規模を 8,000 人と 定めて実施された。この結果、市町村数がほぼ $1 / 3$ に削減された。 その後大がかりな市町村合併は今回の大合併までない。1999 年の法 制定に始まる平成の大合併は、2010 年 3 月末に新合併特例法の適用 期限がきて一応終了した。この合併によって、2000 年 10 月 1 日現在 の全国 3, 230 市町村注 1) が上記期限には 53.5\%の 1, 728 市町村に半 減した主2)。この大合併は構造改革路線の中で少子高齢化への対応 と広域的まちづくりを目指し、職員の効率的配置や市町村の行政 · 財政の効率化等を狙って実施された注3)。この合併の評価には時間 が必要な面もあるが、地域の活力や住民サービスの低下、伝統・文 化など地域のコミュニティ形成上大きな問題が指摘されている注3)。 本研究では、この基本となる日常生活圈域と市町村合併域との関 係を統計的に解析する注4)。日常生活圈に関してはその基本的な要 素である住民の通勤流動を基に設定した住宅市場圈構成注 5) の面か ら捉える。このため、合併の統計分析上の基点を 2000 年国勢調查の 市町村域に置く。この市町村とそれにより構成される住宅市場圈が 合併終了時（2010 年)の合併後市町村との圈域の混交関係の分析に
より、合併市町村域が従来からの住民の日常生活行動圈域に適合し ているか否かの基本的な検証考察を行う。なお、本報では合併後市 町村を構成する 2000 年時市町村の集まりを「合併群」とする。また、 同年の住宅市場圈を構成する市町村の集まりを「市場圈」とする。

資料は平成 12 年国勢調查報告第 1 巻 ${ }^{2)}$ 、総務省の合併実績一覧 ${ }^{4)}$ 、 （財）地方自治情報センターの地方公共団体コード一覧 ${ }^{5}$ )および「住 宅市場圈構成」に関する拙著論文 ${ }^{1}$ ) とその基礎データ (各年次国勢 調查結果注 6)、各時点の市町村域に組替え編集・集計)である。

\section{2. 市町村合併の実態}

\section{2-1）合併関与市町村と合併変化の内容}

合併により市町村数は半減し、平均 3.6 市町村が 1 市町に集約され た。2000 年の 3, 230 市町村のうち、合併に関与した市町村(合併関 与) は $64.7 \% 2,089$ 市町村で、かなり多い(図 1)。一方、合併変化な しは 35. 3\%の 1, 141 市町村 (市制施行 7 を含む)である。この変化の 内訳は、「合併・新市町創設」注7) が 986 (変化総数の $47.2 \%$ )、「他 に編入消滅した市町村」(以下「編入消滅」)が $801(38.3 \%) 、 「$ 他を 編入したもの」注7) (以下「他を編入」) が $302(14.5 \%)$ となる。

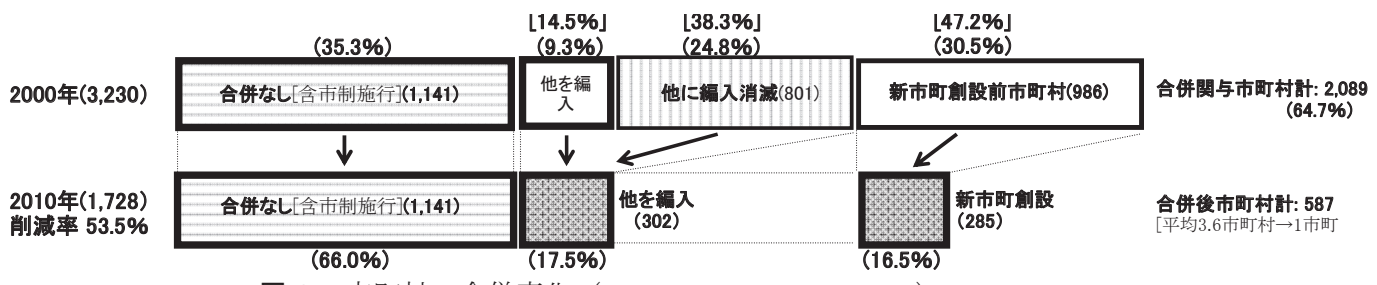

図 1 市町村の合併変化 (2000.10.1 $\rightarrow$ 2010.3.31) 


\section{2-2）合併関与市町村数分布}

個々の合併における合併関与市町村数分布を見ると(図 2 )、2 市 町村合併が 36.6\% (215)、3 市町村合併が 26.4\% (155) で、ここまで で全体の 6 割を越え、個々の合併における合併市町村数はそれほど 多くはない。しかしながら、一方で 10 市町村以上の合併は $1.7 \%$ の 10 市あり、最も多いのが新潟市の 15 市町村の合併、次いで新潟県 上越市の 14 市町村合併で、静岡県浜松市および愛媛県今治市の 12 新潟県長岡市の 11 が続き、新潟県での大規模合併が目につく。

\section{2-3）合併による人口規模変化と関与市町村の規模別合併状況}

このような合併による市町村の集約化は、各市町村の人口規模拡 大を進め、2000 年で半数近くの $48.2 \%(1,557)$ あった 1 万人未満町 村が、2010 年ではこの時点全市町村 1, 728 の $1 / 4$ の 25.5\% (441) に 減り (人口は 2000 年時)、3 万人以上市が 2000 年の $22.0 \%$ (715) から 半数近くの $46.9 \%$ (808) に増える (図 3)。2000 年時点の合併関与市 町村 $(2,089)$ の $84.4 \%(1,763)$ が 3 万人未満であったのが、合併後 (合 併総数 587) では $71.4 \%$ (419) が 3 万人以上となる。一方、合併なし(合 併非関与)市町村 $(1,141)$ の場合は、65. 9\% (752) が 3 万人未満の小規 模市町村であり、多くの小規模町村が未合併のまま残されている。

しかし、合併関与市町村は小規模市町村、特に人口 1 万人未満が 多く ( 1 万未満 1, 557 市町村の $73.2 \% 1,139$ が関与)、人口規模が大 きくなるに従い関与数は減り、 3 万人以上 (715) になると半数を割る （326、45.6\%、図 4)。関与市町村の人口規模から見た合併の姿とし て以下が確認出来る。(a) 3 万人未満の小規模市町村では新市町創設 を第 1 に、これと編入消滅の 2 タイプが主要な動きとなる。(b)一方 3 万人以上のより規模の大きい市等は小規模市町村を編入 ・吸収し てさらに人口規模の大きい市となる編入合併のタイプが主流となる。 (c) 合併非関与市町村は 3-10 万人までは増え、以後 100 万未満まで は漸減するが、100 万以上政令指定都市では非合併が大半を占める。

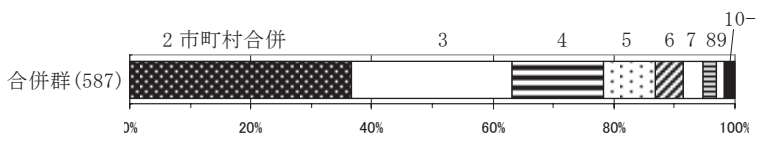

図 2 合併群の合併市町村数分布

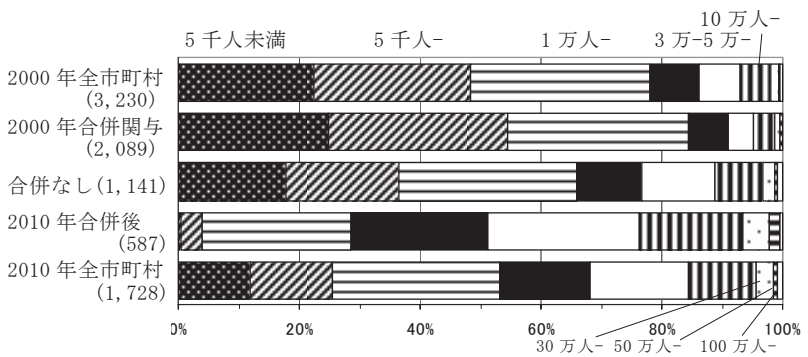

図 3 合併前後合併状況別人口規模分布 (2000 年時点人口)

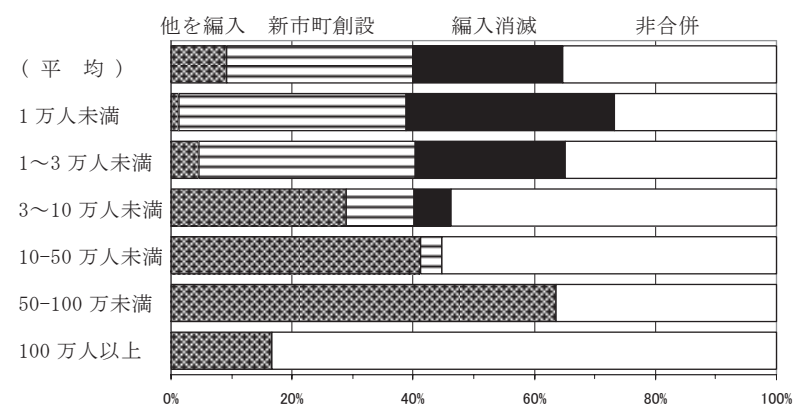

図 4 人口規模別に見た合併状況 (2000 年ベース)

\section{2-4）合併市町村数の地方差}

合併には地方差があり、削減率 ( (2000 年市町村数 -2010 年市町村 数) $/ 2000$ 年市町村数、\%) が高く合併の多い県は南西部 (中国・四国 •九州)の県が多く、削減率が低い地方としては大都市圏の関東、近畿 と北海道や東北の一部、沖䋲などである(表 1 )。しかし、南西部各 県の削減率は多様で、沖縄県は大都市圈並みの低さで、高知・福岡 ・宮崎県 ${ }^{\text {注 }}$ も全国平均を下回る。東北地方は、削減率の低い山形県 から高い秋田県まで多様、北陸地方は平均削減率よりはやや高い範 囲に多いが、大型合併が際立つ新潟県は特に高い。削減率の低い近 畿の中で滋賀・兵庫県 ${ }^{\text {注 }} 8$ は高い。最高削減率は長崎県の $73.4 \%(2000$ 年 79 市町村 $\rightarrow 2010$ 年 21 に大幅削減)、次いで広島 $(73.3 \%$ 、86 $\rightarrow 23) 、$ 新潟 $(73.2 、 112 \rightarrow 30) 、$ 愛媛 $(71.4 、 70 \rightarrow 20)$ の 4 県が $70 \%$ 以上となる。 一方、削減率最低は大阪府 (2.3\%)、東京都 (2.4) で、続いて神奈川 県(10.8)、北海道 (15.6)、奈良県 (17.0) が $20 \%$ 未満となる。

上記に合併関与市町村数を絡めてみると (表 1 )、南西部に多い削 減率の高い県は合併関与市町村数が多い傾向がみられ、削減率最高 の長崎県は半数以上の $53.9 \%$ が 6 市町村以上の合併となっているが、 高削減率県の多くでは 6 市町村以上の合併は 20３0\%程度である。 しかし、このなかで愛媛県は 1 合併都市あたりの合併関与数が少な く、その分合併都市が多いという特徴を持つ。削減率の少ない大都 市圈の関東・近畿および北海道などの都道府県の場合は、1 合併都 市あたりの合併関与市町村もほとんどが 5 市町村以内で少ない。

表 1 県別合併前後市町村数と削減率 (削減率順、上下各 15 位)

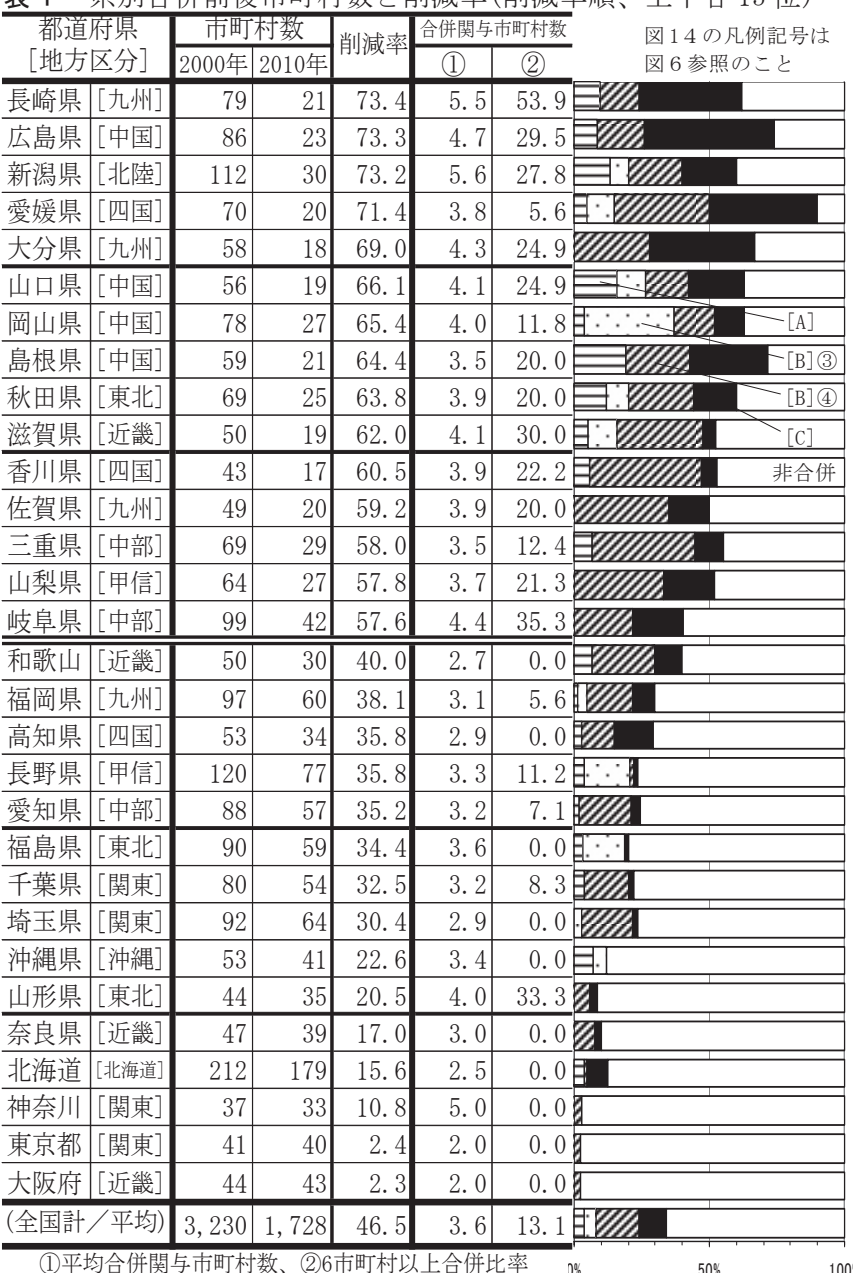

図 14 県別に見た合併市場圏型分布 


\section{3．住宅市場圏構成と合併市町村群の関係}

\section{3-1）住宅市場圏の構成と構成要素別合併状況}

文 1)では、日常生活圈としての住宅市場圈構成を通勤流動による 居住地就業人口における対母都市就業人口流出率 (R S ) によって求 め、作業仮説として市町村相互のつながり境界をR S $5 \%$ 以上とし、 これにより連結される市町村の包括境界範囲を住宅市場圈 (以下、市 場圈と略称) としている(2000 年時点で全国 550 圈)。この圈域構成要 素の市町村種別には、市場圈の中心となる多様な主核 (中心核・連結 核・単独核)、これらと連結する多段階の副次核と衛星都市、および 他につながりのない独立市町村(住宅市場圈の 1 種とする)がある注9) 合併状況を構成要素種別にみると(図 5 )、主核(全 332)の場合は 「他を編入」が最多で $(44.6 \%$ 、148)、合併の中心となる場合が多い。 一方、独立市町村 (218) は過半の $61.5 \%$ (134) が「非合併」であり、 小規模なものが多いこれらが合併の流れから取り残されている状況 を示す。この主要な動きに次いで、主核は「非合併」（29.2\%、97）、 さらに「新市町創設」 $(23.2 \%$ 、 77$)$ が続き、「編入消滅」 $(3.0 \%$ 、 10) は極めて少ない。独立市町村の場合は、「新市町創設」(20.2\%、 44) が続き、「他へ編入消滅」（15.6\%、34）は少なく、「他を編入」 (2.8\%、6) は極めて少ない。副次核と衛星都市の場合は「合併なし」 が $1 / 3$ 程度 $(33.8 \%, 153$ および $34.0 \%, 757)$ で主核よりやや多いが両 者には大きな違いはない。これらは「新市町創設」が 3 割強(34.7 \%, 157 および $31.8 \%, 708)$ となり、比較的中小規模のこれらの市町 村が共同で新しい市等を形成する場合がかなりあることを示してい る。これに続いて副次核は「他を編入」 $(23.0 \%, 104)$ 、衛星都市は 「他へ編入消滅」 $(32.2 \%, 708)$ が多いが、都市としての位置づけの 違いを反映していよう。副次核の「編入消滅」 $(8.6 \%, 39)$ と衛星都 市の「他を編入」 $(2.0 \%, 44)$ は極めて少ない。このように市場圈構 成要素によって合併の仕方の違いが見られる。

\section{3-2）合併市町村群から見た合併群と住宅市場圏域との関係}

合併後市町村 (587、424 市 158 町 5 村) を構成する 2000 年の合併 群 (1.で定義している) と市場圈域の関係を合併群単位でみてパタ ーン化すると図 6 のようになる。大きくは I のように合併群が単一 の市場圏で構成されるものと、II のように合併群が複数の市場圏 (独 立市町村を含む)で構成されるものに大別される。I には $[\mathrm{A}]$ 市場圈 範囲内に他の合併群がないもの (1)市場圈が合併群のみ、(2)市場圈内 に非合併市町村があるものに細分)、[B]市場圈内に複数合併群があ るもの (3)圈内他合併群も当該市場圈内にあるもの、(4)他合併群が別 の市場圈内市町村に及ぶものや独立市町村と合併に細分) がある。ま たIIには、(5)のように [A] に独立市町村が加わったり、独立市町村 同士の合併などのそれほど複雑な地域構成に至らないものと、(6)合 併群内市場圏に入る他の合併群が複数の市場圈に跨って構成され圈 域全体として複雑な地域構造となるものがある。

合併群が同一市場圈で構成される I の合併群は 7 割 $(71.2 \% 、 418$ 群）となるが、合併群内に複数市場圈が関与寸る II は 3 割（28.8\%、 169 群) で(図 7 上)、後者は合併が日常生活圈域と明らかに混交して いる。また、7割を占める I のなかでは、市場圈がひとつの合併群 のみの [A] 1 1 割（11.9\%、70 群）にすぎず、市場圈が合併群と混 交しない複数合併群内在の [B] (3)の場合が 1 割強 (12.3\%、の 75 群) となり、併せて 2 割強にとどまる。I の残りの 5 割弱の [B] (4) (46. $5 \%$ 、273 群) は、自身は単一市場圏の合併群ではあるが同一市場圏

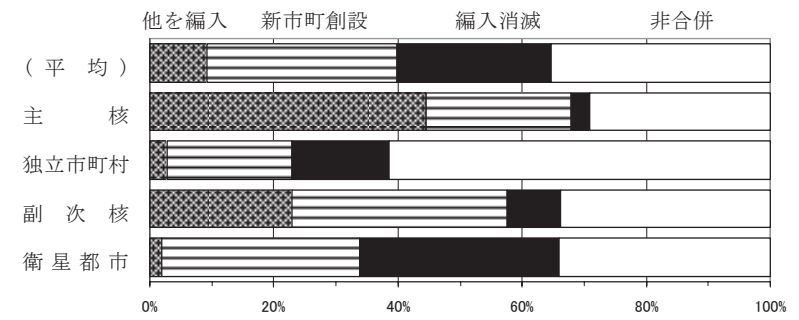

図 5 市場圈構成要素別に見た市町村の合併変化状況分布 (2000)

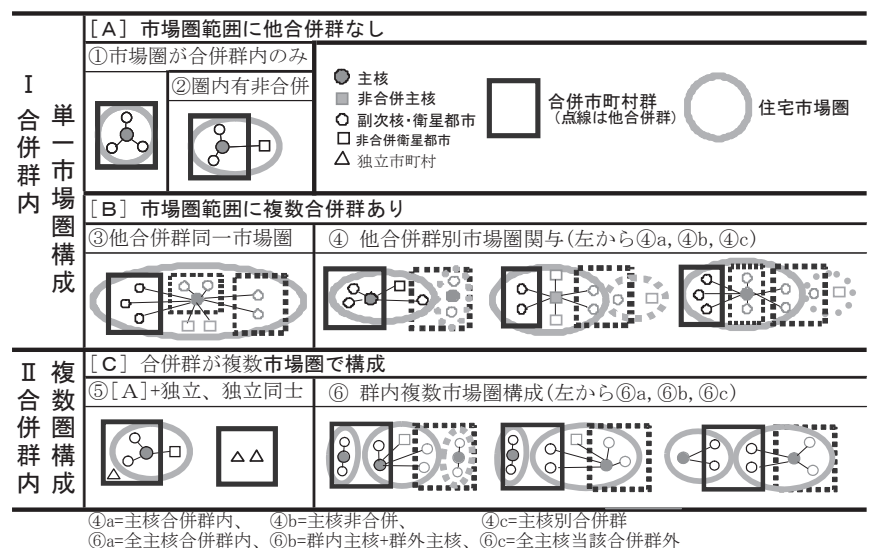

図 6 合併群の合併市場圈型のパターンモデル

2010 合併群 (580) 2000 合併関与 $(2,089)$

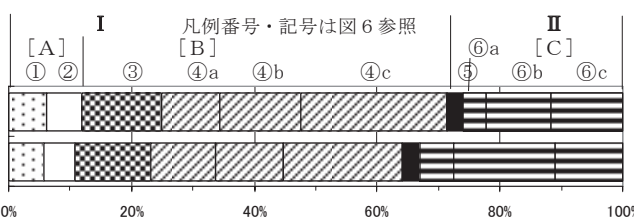

図 7 合併群の合併市場圈型

内にある他の合併群が複数の市場圈や独立市町村に跨る合併群とな るもので、市場圈範囲での複雑な合併構造の一翼を担う形となって いる。これと II をあわせると、8 割近くの合併群が、市場圈の広が りの中で合併による地域構造の混交にかかわっていることになる。 なお、これらの合併状況を合併前の関与市町村単位で見ると(図 7 下)、IIIタイプに入る市町村の比率が増え (36.0\%、751 市町村)、 旧市町村単位で見ると地域構造の混交の影響がより大きく見える。

\section{3-3）住宅市場圏における合併群の存在状況}

市場圈単位でみた合併群の存在状況のパターンモデルは図 8 のよ うになる。 550 市場圈のうち、合併市町村がないもの ( 1 ) は 181 圈 (32.9\%)、あるもの ( $2 \cdot 3$ ) は 369 圈 (67.1\%) となる(図 9 上)。す心゙ ての合併群が単一の住宅市場圏に納まる 2 は 98 圈 (17.8\%、有合併 市場圏の $26.6 \%$ ) にすぎない。従って、合併のない 1 と市場圏と合 併群との混交のない 2 の市場圏は、あわせて半数の 271 圏 (49.3)に 留まる。2のうち 70 圈 (12.7\%) は内在する合併群は単一であり (b1)、 市場圏内に複数合併群があるもの (b2) は 28 圈 (5.1) となる。

一方、住宅市場圈外に遡及する合併群がある ( 3 ) では、（2）の一 部に市場圈外の独立市町村が加わり複雑性が若干増したもの（3c) は 28 圏 (5.1\%、有合併の $7.6 \%)$ ある。また、独立市町村と他の合 併 ( 3 d ) は 84 (15.3、同上 22.8)、さらに圈内合併群が複数市場圈に 跨るより複雑な圈域構成 ( 3 e) は 159 圈 (28.9、同上 43.1$)$ となる。 このなかで $\mathrm{e} 2(64$ 圏、11.6\%)、e3 (41、7.5) は市場圈内に合併群が複 数あり、とくに e3 は複数の合併群が複数の市場圈・独立市町村に 


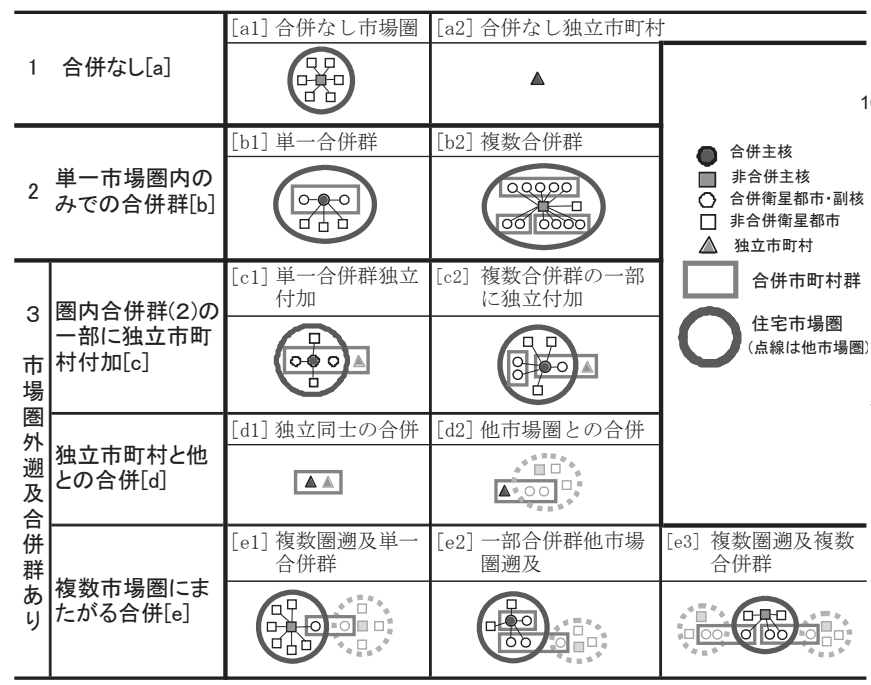

図 8 住宅市場圏の合併状況型パターンモデル

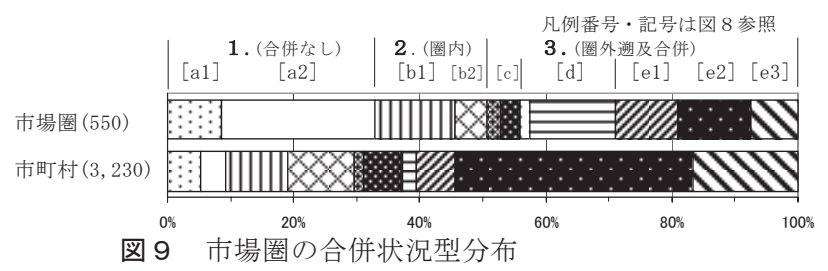

跨る最も複雑な圈域構成を示している。なお、 $3 \mathrm{~d}$ の独立市町村の 合併のうち、独立市町村同士の合併 (d1) は 9 圈 (1.6) で、他 (d2)の 75 圈 (13.6) は 3 e の合併群を構成する合併群内独立市町村である。

これを市場圏の市町村単位でみると (図 9 下) 、 22 の圈内合併群の 一部が他市場圈に遡及するタイプの合併群を持つ市場圈に属する市 町村が $37.6 \%$ (1214 市町村)に、e3 の複数圈遡及複数合併群をもつ 市場圏の市町村が 16.6\% (536) に増え、非合併市町村は減少する。

\section{3-4） 2000 年の市町村単位で見た合併群と住宅市場圏との関係}

2000 年時点の市町村における合併関与・非関与数は 2-1) で示した。 この合併関与市町村のうち合併群が単一の市場圈に限定されるもの ( I ) は 41.4\% (合併関与市町村の $64.0 \%$ )の 1, 338 市町村となるが (図 7 下)、これは合併後市町村の 418 合併群 (合併群全体の $71.2 \%$ ) に対応する。一方、合併群範囲内に複数の市場圈がある合併群を構 成寸る市町村（II）は 751 市町村 $(23.2 \%$ 、合併関与全体の $36.0 \%$ ) と なり、これらが合併後市町村の $28.8 \%$ (169 合併群)を構成している。

これらの合併関与市町村に非合併市町村を加えて、市町村単位で 合併群構成と市場圏構成との関係をみてみよう(図 10 )。図の横軸 は合併群構成市町村の合併市場圏型分布で、総数の分布は図 7 下段 に非合併分を加えた分布を示しており、図の縦軸は市場圏構成市町 村の合併状況分布でその総数は図 9 下段にその分布を示している。 合併群の [A]を構成する市町村 (226、全体の 7.0\%) と [B] (3) (257、 8. $0 \%$ ）は全て市場圈の [b] に属し、両者を併せた 483 市町村 (15.0\%) に関しては合併群が全てひとつの市場圈に納まる市場圈に属してい る。[b]にはこの他に非合併市町村が $172(5.3 \%)$ ある。合併群の [B] (4)を構成する市町村 $(855 、 26.5 \%)$ は、市場圈の [c] (87、2.7\%)または [e] $(768 、 23.8 \%)$ に属するが、それらの合併群自体は当該市場圈内に 納まったものである。これらの合併群と同じ市場圏に属するが、複 数市場圈に跨る合併のある他の合併群の市町村が [C ] (5) (61、1.9\%)

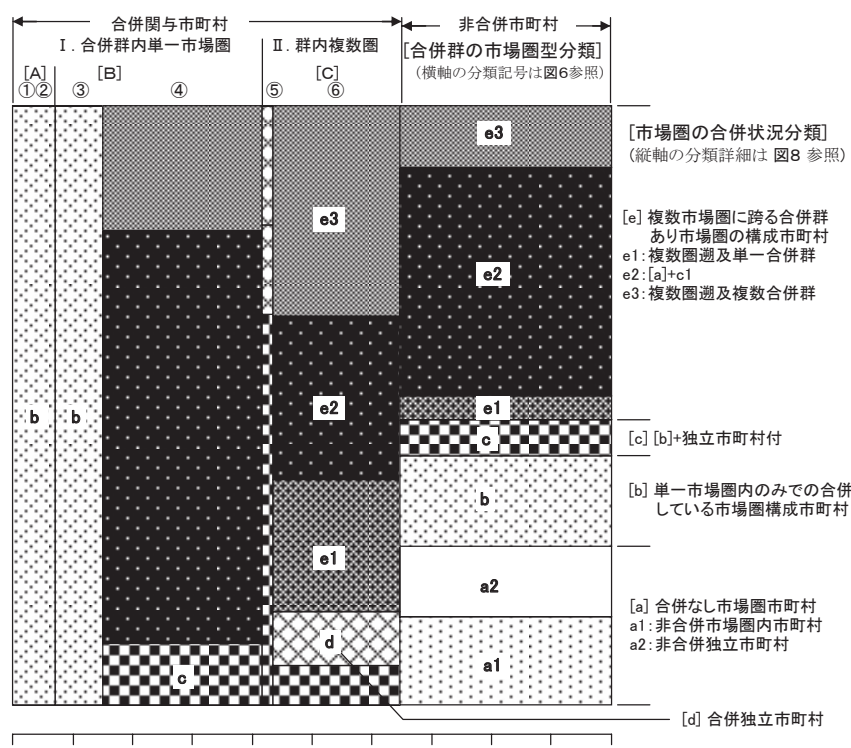

図 10 市町村 5 \% 合併群・市場圏構成

および(6) (690、21.4\%) となる。このうち、合併群(5)の市場圈構成は [c]の市場圈構成市町村 (39、1.3\%) および $[\mathrm{d}]$ の独立市町村 $(22 、 0$. 7\%)である。また、合併群(6)場合の市場圈構成市町村は多様で、[c] が $45(1.4 \%) 、[\mathrm{e}]$ が $583(18.0 \%) 、[\mathrm{~d}]$ が $62(1.9 \%)$ となるが、 [e] の 複数市場圈に跨る合併群がある市場圈構成は、 $[\mathrm{e} 1]$ の複数圈遡及単 一合併群 (153、4.7\%)、[e2]の市場圈内に圏内のみ合併群の他にひ とつの他市場圈遡及合併があるもの $(187 、 5.8 \%)$ 、[e3]の複数の複 数圈遡及合併群があるもの $(243 、 7.5 \%)$ が多様に存在する。これに 対して、合併群の (4)では、市場圈の [e2]が主流となり (590、18.3\%)、 [e3]はやや少ない $(178 、 5.5 \%)$ 。従って、合併群 [C] は市場圈構成 に対してより複雑な地域構造の要素となっているといえる。非合併 市町村では、先に示した市場圈の [b]以外は $[\mathrm{c}]$ が $70(2.2 \%) 、[\mathrm{e}]$ が 597 (18.5\%、内 e1 が 45、1.4\%、e2 が 437、13.5\%、e3 が $115 、 3$. $6 \%)$ 、[a]の合併なし市場圏を構成している市町村が $302(9.3 \%$ 、a1 の一般市場圏構成非合併市町村が $168 、 5.2 \%$ 、a2 の非合併独立市町 村 $134 、 4.1 \%)$ となり、[e2]の単一市場圈内合併群之複数圈遡及合 併群が混在する市場圈に入る非合併市町村の占める比率が高い。

\section{4 合併群諸市町村のその他の特徵 4-1）合併の市町村数規模分布}

合併群の合併市町村数の基本分布は図 2 で説明しているが、図 7 に示寸合併市場圈型別に見ると (図 11 上段)、複数市場圈に跨る合 併群の場合（II の [C ] ) は単一市場圈に納まる合併群 ( I )の諸タイプ ([A]、[B] (3)(4)) より大規模合併が多く、小規模合併は少ない。即 ち [C] 5 市町村以上合併の全体で $1 / 3$ を越える $36.1 \%$ となり、単 一市場圏に納まる合併群 ( I )の諸タイプのもの (15.2-18.5\%)より 多い。この反面、 [C]の場合は 3 市町村以内の小規模合併は 47.4 \% (2市町村合併 $23.1 \%$ 、3市町村合併 $24.3 \%$ ) で半数に満たないが、 I の諸タイプの場合は半数をかなり超え多い $(62.7 \sim 71.1 \%)$ I の うち自らは関与市場圈内合併に納まるが、同一市場圈内にある他の 合併群が市場圈外遡及合併のもの ([B] (4)) は 2 市町村合併が多く

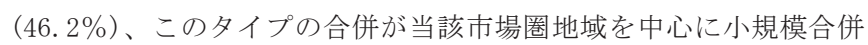
が複雑に絡み合った圈域構造の要素となっていることを示している。 


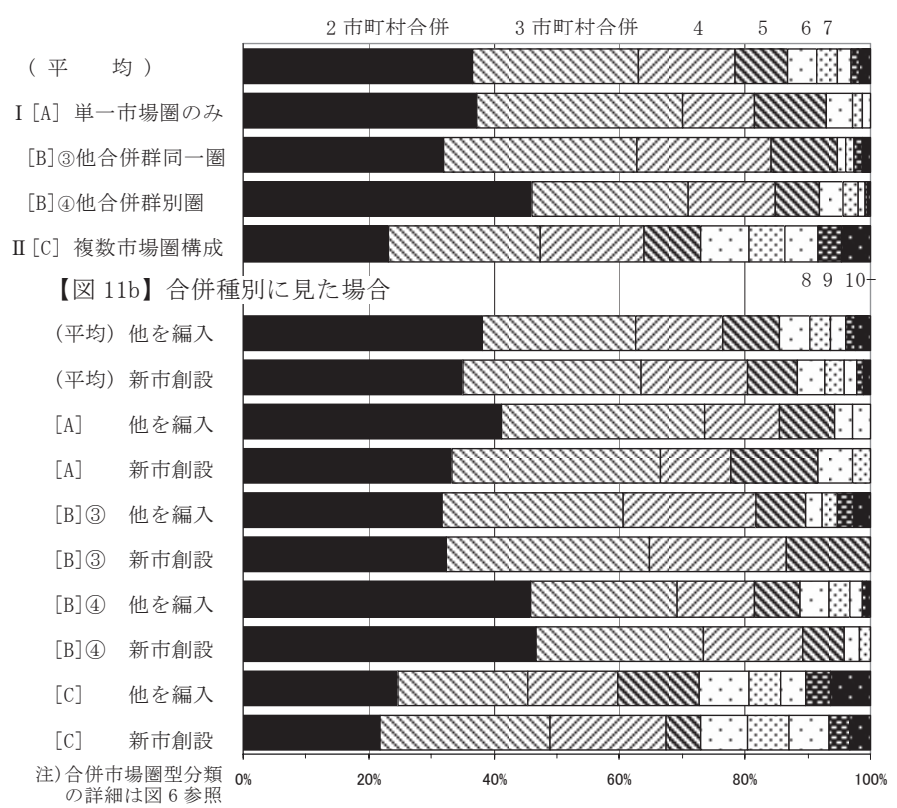

図 11 合併市場圈型別に見た合併群の合併市町村数分

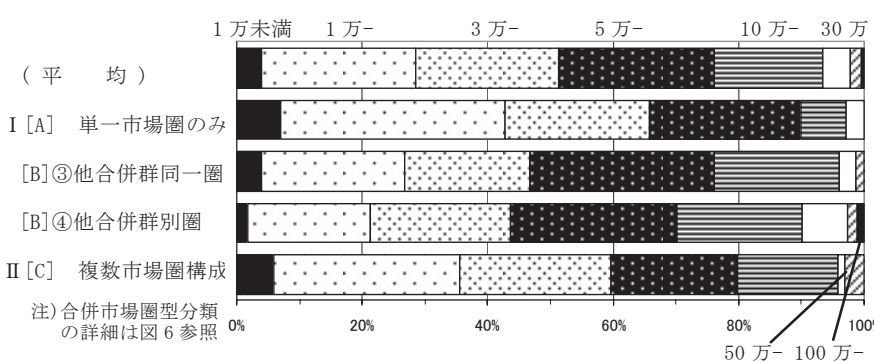

図 12 合併市場圈型別に見た合併群の人口規模分布

\section{4-2）合併群の人口規模分布}

これらの合併状況を合併後の人口規模分布で見てみよう（図１２、 人口は 2000 年時点)。合併後の人口規模上昇の全体状況は図 3 で説 明している。合併市場圏型別に見ると、単一市場圈での単一合併群 の場合 ([A]) では 5 万人未満が $65.7 \%$ で合併後も小規模なものが最 も多く、次いで複数市場圈に跨る合併群の場合（II [C])で $59.8 \%$ と なる。単一市場圈内で他の合併群もある [B]の (3)(4)の 2 つのタイプ の場合は 5 万人未満が半数を割りやや少ないが $(46.7 \%$ よび 43.6 \%)、その反面合併後 10 万人以上となる場合が多い(4)が最多の 29.7 \%、(3)も $24.0 \%$ )。一方、[A]は 10 万人以上が $10.0 \%$ で最も少なく、 [A] が小規模市町村の合併の主要なタイプであることが分かる。

以上から、[B] (4)のグループは合併市町村数が少ない割には合併 後人口規模が大きく、比較的人口規模の大きい市町村が関わる合併 のタイプで、 [B] (3)がそれに次いでいる。複数市場圈に跨る合併群 の [C ～（II）はより多くの市町村が合併することによりある程度の合 併後人口規模を確保寸るが、同一市場圈に関わる [B] (4)の合併群よ り人口規模は少ないものが多い。これは、市場圈域内で(4)は中心部 地域の市町村の合併、[C]は比較的外周部で合併群範囲が市場圈外 に及ぶ存在の場合が多いことを示していよう。[B](3)市場圈域の やや多くの市町村が合併することにより人口規模が若干大きい状況 を作り出す。[A]も市場圈の多くの圈域をひとつに合併することに より成り立つが、合併群を構成する市町村自体が比較的小規模なた め、合併後の人口規模はそれほど大きくはならないものが多い。

\section{4-3）合併群の合併種別とその合併規模}

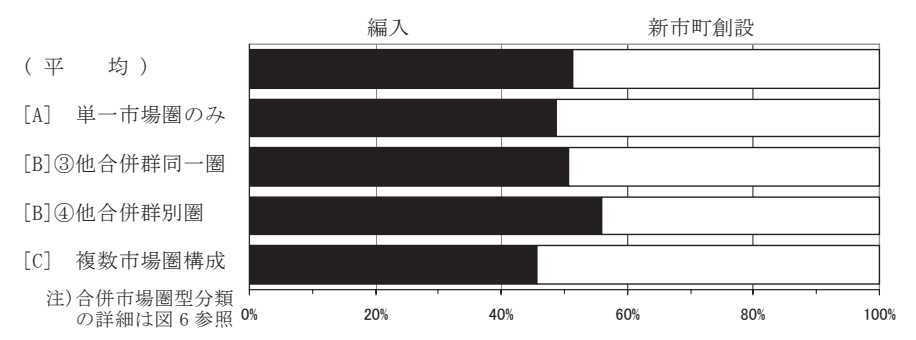

図 13 合併市場圈型別に見た合併群の合併種別分布

合併群の合併種別分布は、全体平均で「他を編入」が $51.4 \%$ 、「新 市町創設」が $48.6 \%$ で、前者がやや多いが差は殆どない(図 13 )。 しかし合併市場圈型別に見ると、複数市場圈に跨る合併群の場合 ([C]) は「新市町村創設」がやや多く (54.4\%)、[B] (4)はやや少な いが(44.0)、[A]と [B] (3)は共に全体平均に近く、 [C c と [B] (4)の 中間に位置し、「他を編入」と拮抗する。

この状況を 4-1) で明らかにした合併の市町村数規模分布と絡め てみると (図 11 下段)、2-3 市町村程度の小規模合併の段階では [A] における「他を編入」（両合併数併せて $73.6 \%$ ）の方が「新市町村 創設」 $(66.6 \%)$ より多い他は合併市場圈のタイプ別に大きな差はな い。しかし、5市町村以上の比較的合併数の大きな段階では、 [A] は上記の影響を受けて「新市町村創設」 $(22.3 \%)$ の方が「他を編入」 (14.6\%) より多いが、他のグループでは「他を編入」の方が多くな り、特に全般的に合併市町村数の多い [C]の場合は「他を編入」が $40.3 \%$ に達し、「新市町村創設」(32.6\%)より合併市町村数は多い。

\section{4-4）合併状況の地方差}

表 1 を踏まえて、合併終了時点での合併結果から合併状況の地方差 を検討する (図 14 表1 横厄揭载)。2010 年現在の非合併市町村を含めた 全市町村中の合併済み市町村 (合併群)の比率の最高県は愛媛 (90.0 \%、全県 20 市町村中 18 が合併)である。これに次いで広島 (74. $9 \%$ 、 23 中 17 合併)、島根 $(71.4 \% 、 21$ 中 15)、大分 (66.7\%、18 中 12) まで が県内の $2 / 3$ 以上の市町村で合併が実施された。これらに山口、岡 山、長崎が 6 割以上で続き、中国・四国・九州の南西部地方の合併 が多く、新潟、秋田などの東北・北陸地方の幾つかの県も多い。一 方、合併群比率最少は大阪 (2.3\%)、東京 $(2.5)$ 、神奈川 (3.0) の大都 市圈都府県と山形 (8.6)で、10\%に満たない。合併内容をみると、複 数市場圈に跨る合併 $([\mathrm{C}])$ の多い県は広島 $(47.8 \%) 、$ 愛媛 $(40.0)$ 、大 分 (38.9)、長崎 (38.1) で、日常生活圏域との混交が南西部地方で多 いことが分かる。合併群の全市町村が単一の市場圈に納まり日常生 活圈域との混交がないタイプの合併([A]と [B](3))の多いものは、 山口 (46.3\%)、岡山 (37.0)、鳥取 (31.6) などの南西部の一部県が多く、 長野 (20.8)、新潟 (20.0)、秋田 (20.0) が続く。合併なし市町村が 90 \%以上の都府県を除き、合併群が単一市場圈に納まる合併が全くな い県は杤木注 10 ) 、福井注 10 )、山梨、岐阜、奈良、佐賀、大分の 7 県に及ぶ。 なお、非合併を除いて合併したもののみで見ると、上記の状況は 若干異なり、広島 (合併群中 $64.7 \%$ ) ・長崎 (61.5) ・ 大分 (58.3) にお ける複数市場圈に跨る合併 ([C] ) の多さは変わらないが、愛媛 (44. 4) はやや比率が下がる。これに対して、北海道 (59.1)、高知 (50.0)、 岐阜 (47.1)、徳島 (40.0) 注 10)、京都 (40.0) 注 10) の 5 道府県は複数市 場圈に跨る合併 $([\mathrm{C}])$ が全体の 4 割を越え、比較的多い。これらは それほど多くない合併のなかで日常生活圈域との混交が比較的多い ことを物語っており、特に北海道の場合は市町村の行政域が広いた 
め、各市町村域の日常生活圏域としての完結性が高いことから、こ のような状況を作りや寸い状態となっている。

\section{5.まとめ}

以上をまとめると、以下に要約される。

(1)平成大合併の 10 年間で市町村数は半減し、2000 年全市町村の 6 $5 \%$ が合併に関与した。しかし、その合併は $2 \cdot 3$ 市町村の小規模合併 が主流で (6 割超)、10 市町村以上 $(2 \%)$ などの大規模合併は少ない。 (2)合併により人口規模は拡大寸る。合併関与市町村の半数は人口 1 万人未満の小規模であるが、合併後は 3 万人以上が 7 割に達する。

(3)人口規模段階によって合併の椂相は大きく異なる。大規模都市、 特に 100 万人以上での合併は極めて少ない。それ以下では 3 万人を 境に大きく異なる。まず、非合併は 3 万人未満では $1 / 4$ 前後である が、それ以上 50 万人未満では半数を超える。合併種別では 3 万人未 満の小規模市町村では新市町創設型、次に編入消滅が多いが、3 万 人以上では編入型が過半を占め、しかも 100 万人までは急増する。

(4)市場圈の構成要素で合併種別が異なる。市場圈中心の主核の場 合は編入型が主流、副次核では新市町創設と非合併が共に $1 / 3$ で編 入消滅は少ない。衛星都市は編入消滅、新市町創設、非合併が共に $1 / 3$ 程度で編入型以外の多様な合併が見られる。独立市町村は非合 併 6 割で多く、特に小規模市町村が合併の流れに取り残されている。

(5)合併群構成と市場圈構成の関わりを合併群側から見ると、合併 群の 7 割は単一市場圈に納まるが、その中で関与する市場圈内にあ る他の合併群も同一の市場圈に納まるものは 2 割にすぎない。つま り、合併群の 5 割で関与市場圈内の他の合併群が複数市場圈に跨り、 地域構造の複雑さに関わっている。一方、合併群が複数市場圏に跨 る市町村で構成される場合が 3 割あり、上記と併せて 8 割の合併群 が市場圈との複雑な地域構造上の混交に関係している。また、ひと つの市場圈に複数合併群があり、自らは単一市場圈で構成される合 併群の場合の人口規模は大きく、複数市場圈に跨る合併群の場合は それほど規模が大きくない。これは、前者が市場圈域の中枢部にあ り、後者が圏域の外周に位置する場合が多いことを示していよう。

(6)市場圈で見ると、7 割弱の市場圏内で合併がなされ、それらの 合併群が市場圈内に納まる市場圏は 2 割に満たない。一方、合併市 町村のない市場圈は独立市町村を含めて $1 / 3$ あり、合併群との混交 がない市場圈は 5 割に留まる。残り 5 割は複数市場圈に跨る合併群 を内在する一般市場圈 (3 割強) と合併独立市町村 (1.5 割) である。

(7)2000 年時点の市町村単位で合併群と市場圈のかかわりをみる と、合併群を構成寸る市町村が同一市場圈に納まるものは 4 割に留 まる。このうち、所属市場圈内にある合併群で複数市場圈に跨らな い合併群の構成市町村は全体の 1.5 割に留まる。複数市場圈に跨る 合併群を構成する市町村は 3 割弱あり、それらには多様な合併群・ 市場圈関係のタイプが存在し、複雑な地域構造の要素となっている。

(8)合併状況には地方差があり、合併による市町村数削減率の高い 地方は南西部の中国・四国・九州の県が多く、低く合併の少ない地 方は大都市圏の関東・近畿と北海道や東北の一部の県、沖縄県であ る。一方、合併期終了時点 (2010 年) で合併済みの市町村 (合併群)の 比率の高い県は上記南西部地方の県が多く、次いで東北・北陸の幾 つかの県が多いが、削減率の高さとは一致しない。合併状況では、 削減率の高い南西部県で合併群が複数市場圏に跨るものが多く、日
常生活圈域との混交がある合併がこの地方に多いことを示している

以上、平成の大合併が従来の住宅市場圈との混交が多く、日常生 活圈域の分断に関わっているものが少なくないこととその状況を明 らかにした。このことを踏まえると、今後これらの合併後市町村で は地域活力の向上策や住民サービスの向上等の内部コミュニティへ の配慮が重要な課題となる。また、国が積極的に推進してきた平成 の大合併は制度上一応終息したが、今後とも行政効率などを求めて の合併の動きは残っている。このため、今後はこの研究の視点であ る住民の日常生活圈構成からの吟味を加えた検討が必要であろう。

なお、本論文の続編として、日常生活圈構造の変化と合併域との 関係、さらに関連する人口変化との関係の分析に取り組みつつある。

注

注 1) 文 2) 第 11 表による。なお、この資料では東京都特別区部は 1 市として 算定しており、本研究でもこれに従っている。

注 2）文 4)の合併統計値には東京都特別区部は含まれていない。

注 3）合併終了時の文 3)の「総務省報道公表文」によると、平成の大合併で は市町村行政における専門職員等の効率的配置などによる住民サービ 又提供体制の充実強化や・公共的施設の統廃合などの行政効率化が図ら れた。その反面、すでに周辺部市町村などの旧市町村の活力喪失、住民 サービス低下、住民の声の行政中枢部への届きにくさ、地域の伝統・文 化・歴史的地名などの啔失が問題としてあげられている。つまり、昭和 の大合併の目的が有効なコミュニティ形成にあったのに対して、平成の 大合併はコミュニティ形成上大きな問題を抱えて実施されたといえる。

注 4）本研究は、文 6)での予備検討段階の研究を踏まえて、平成の大合併が終 了した時点で、新たな分析視点と解析操作を加えて再検討をおこなった ものである。なお、本報告は文 7) をもとに、さらに検討を加えている。

注 5）文1)による。この研究は、日常生活の基点としての住宅を中心に職住 関係の面からその圈域構成を住宅市場圈として捉えている。この住宅市 場圈は、各市町村の就業者の通勤先母都市に対する通勤流出率 (対母都 市通勤就業者数／居住地就業者数、\%) 5\%を仮説基準として設定した。

注 6) 本報告では主として、各年次国勢調査の「従業地・通学地による人口」 (2000 年は第 6 巻) および文 2 )を使用している。

注 7）「合併・新市町創設」は合併によって名称と市町村コード(文 5)が変わ ったもの、「他を編入」は従前の市町村名と市町村コードは変わらない 以前のままのものとしている。つまり、文4)の「合併方式」の説明と は別解釈となっている。例えば、文 4)では福岡県宗像市は「新設」と なっているが、旧宗像市と旧玄海町が合併し、宗像市の名称と都市コー ドは変更されていないので、本研究では「他を編入」としている。

注 8) 紙数の都合で表の掲载枠外にあるが、宮崎は $40.9 \%$ 、兵庫は 53.4 となる。

注 9) これらの構成要素で形成される住宅市場圈構成種別として、中心核と副 次核をもつ複合核圈、主核と副次核相互に主核・副次核の関係となる連 結核圈、副次核を持たず主核と衛星都市からなる単独核圈、および副次 核・衛星都市ともに持たない独立市町村がある(詳細は文 1 参照)。2000 年時点の全国 550 市場圈の構成種別内訳は複合核圈が $107(19.5 \%)$ 、連 結核圈 92 (16.7)、単独核圏 $133(24.2) 、$ 、独立市町村が $218(39.6)$ となる。 なお、構成要素種別市町村分布は、主核が $10.3 \%$ (332)、独立市町村 6.7 $\%(218)$ 、副次核が $14.0 \%$ (453)、衛星都市が $68.9 \%$ (2, 227) である。 注 10）上記注 8)の表の部分割愛に伴いこれれらは図の中間の掲載域外にある。

\section{参考文献}

1）眞嶋二郎·他：住宅市場圏構成の 1955-2000 年の変化動向一住宅需要構造 の地方性に関する基礎分析一、日本建築学会計画系論文集№.586、 pp. 135-140、2004. 12.

2）総務省統計局：平成 12 年国勢調査報告第 1 巻人口総数、日本統計協会、 2002.3

3）総務省：「平成の合併」についての公表 (報道公表文) http://www. soumu. go. jp/gapei/gapei.html 2012.5.1. 参照

4）総務省：平成 11 年度以降の市町村合併の実績及び予定、 http://www. soumu. go.jp/gapei/gapei_h11iko.html 2010.10.1 参照

5）（財）地方自治情報センター：地方公共団体コード住所一覧、 http://www. lasdec. or. jp/cm3/1.0.14.html 2010.10.1 参照

6）眞嶋二郎：日常生活圈としての住宅市場圈構成から見た市町村村合併に 関する一考察、『都市学研究』(北海道都市地域学会) no. 44、2007.9

7）眞嶋二郎：住宅市場圈構成から見た平成市町村大合併の検討、日本建築 学会大会学術講演梗概集 F-1、pp. 1403-1404、2011.8. 